\title{
Step-wise evolution of temperature-mediated phenotypic plasticity in eyespot size across nymphalid butterflies
}

\author{
Authors \\ Shivam Bhardwaj ${ }^{1,}{ }^{*}$, Lim Si-Hui Jolander ${ }^{2}$, Markus R. Wenk ${ }^{1,2}$, Jeffrey C. Oliver ${ }^{3}$, H. Frederik Nijhout ${ }^{4}$ and Antónia \\ Monteiro ${ }^{1,5, *}$ \\ 1) Department of Biological Sciences, National University of Singapore, Singapore \\ 2) Department of Biochemistry, National University of Singapore, Singapore \\ 3) Office of Digital Innovation \& Stewardship, University of Arizona, Tucson, AZ, USA \\ 4) Department of Biology, Duke University, Durham, NC, USA \\ 5) Yale-NUS College, Singapore \\ *) Corresponding authors
}

\section{Abstract}

There are two disparate views regarding phenotypic plasticity. One regards plasticity as a derived adaptation to help organisms survive in variable environments ${ }^{1,2}$ while the other views plasticity as the outcome of flexible, non-canalized, developmental processes, ancestrally present in most organisms, that helps them colonize or adapt to novel environments ${ }^{3-5}$ e.g., a pre-adaptation. Both views of plasticity currently lack a rigorous, mechanistic examination of ancestral and derived states and direction of change $^{2}$. Here we show that the origin of phenotypic plasticity in eyespot size in response to environmental temperature observed in Bicyclus anynana butterflies is a derived adaptation of this lineage. Eyespot size is regulated by temperature-mediated changes in levels of a steroid hormone, 20E, that affects proliferation of eyespot central cells expressing the $20 \mathrm{E}$ receptor $(\mathrm{EcR})^{6,7}$. By estimating the origin of the known physiological and molecular components of eyespot size plasticity in a comparative framework, we showed that $20 \mathrm{E}$ titer plasticity in response to temperature is a pre-adaptation shared by all butterfly species examined, whereas the 
31 origin of expression of EcR in eyespot centers, and the origin of eyespot sensitivity to the hormone-receptor complex are both derived traits found only in a subset of species with eyespots. The presence of all three molecular components required to produce a plastic response is only observed in B. anynana. This gradual, step-wise, physiological/molecular response to temperature is a likely adaptation to temperature variation experienced across wet and dry seasons in the habitat of this species. This work supports, thus, the first view of plasticity as a derived adaptation.

The two views on phenotypic plasticity articulated above, as an adaptation or a preadaptation, require either that plasticity evolves under natural selection or that it is ancestral and widespread and facilitates adaptation. Several case studies have been documented in support of the first ${ }^{8-10}$, and second evolutionary scenarios ${ }^{11,12}$ but to date, almost nothing is known about how the original plastic responses underlying both hypotheses originated and evolved at the proximate, mechanistic level. Details of how plasticity originates, and whether or not it is widespread and ancestral to a group of species, regardless of their current living environments, may also help discriminate between plasticity being a facilitator or a consequence of organismal adaptation.

A comparative approach that addresses the mechanistic origins of plasticity needs grounding in a sufficiently well understood molecular mechanism of plasticity. Here we use dramatic seasonal variation in the size of $B$. anynana wing eyespot patterns as our case study. Bicyclus species live throughout dry and wet seasons in Africa, where eyespots of different sizes serve different ecological roles ${ }^{13,14}$. In the hot wet season, the large exposed ventral eyespots help deflect attacks of invertebrate predators towards the wing margins ${ }^{15}$, whereas in the cool dry season the smaller eyespots help in camouflage against vertebrate predation ${ }^{16}$. 
57 Eyespot size plasticity in B. anynana is mostly controlled by temperature, which leads to variable titers of the hormone 20-hydroxyecdysone (20E) at the wandering (Wr) stage of larval development $\mathrm{t}^{6}$. Manipulations of $20 \mathrm{E}$ signaling alone, at that time in development, are sufficient to modify eyespot size $\mathrm{s}^{6}$ Upon sufficient $20 \mathrm{E}$ signaling, these central cells divide and produce a larger central group of signaling cells ${ }^{7}$ and ultimately a larger eyespot. Given knowledge of how eyespot size plasticity functions in one species, we sought to investigate how this system of temperature sensitivity evolved by performing a comparative study across nymphalid butterflies, with and without eyespots.

Eyespots originated once within the nymphalid family, about 85 mya, likely from preexisting simple spots of a single colour ${ }^{17,18}$ but it is unclear whether size plasticity in response to temperature evolved before or after the origin of eyespots. If eyespot or spot size plasticity is an ancestral pre-adaptation, it is possible that even species of butterflies that do not experience seasonal environments (such as those living near the equator), might have the ability to develop different eyespot or spot sizes when reared at different temperatures under experimental conditions. Alternatively, if eyespot size plasticity is an evolved adaptation, used exclusively by species living in seasonal environments, then only these species should exhibit plasticity.

To test these hypotheses, we reared twelve species from different nymphalid subfamilies, and from tropical, or sub-tropical regions, plus one outgroup papilionid species (Table S1) at two different temperatures, separated by 10 degrees Celsius, and measured eyespot size plasticity in adult females. Three different types of reaction norm to rearing temperature were observed across species (Fig. 1A). Five species showed no significant difference in hindwing (HW) Cu1 eyespot size when reared across two temperatures and were deemed not plastic. Most species showed a 
84 decrease in eyespot size with an increase in temperature and had a negative slope in their reaction norms. B. anynana was the only species which displayed a positive slope in its reaction norm, where eyespot size increased with temperature ${ }^{13}$ (Table S2). Ancestral character state reconstructions for the slope of these reaction norms suggested that eyespot size plasticity of any form is a derived trait within nymphalids, with three or four possible independent origins. Ancestral species of nymphalids lacked plasticity, whereas there were two or three independent origins of a negative response of eyespot size to increasing temperature and a separate origin of the opposing pattern of plasticity in ventral HW eyespot size in the lineage leading to $B$. anynana (Fig. 1B).

To investigate the molecular basis for these different patterns of plasticity we looked at $20 \mathrm{E}$ titers and EcR expression across species using female data. 20E titers at the Wr stage were consistently higher at the higher rearing temperature across all butterflies (Fig. 2a) (Table S3), suggesting that 20E titer plasticity in response to temperature is an ancestral trait shared across these butterflies. EcR expression at the Wr stage was absent from spot centers in species with simple spots, but was present in the eyespot central cells across all species investigated, with a few exceptions (Junonia coenia and Junonia almana) (Fig. 2B). This suggests that EcR localization in eyespots is a derived trait, present only in species with eyespots.

Finally, to test whether eyespots expressing EcR are size regulated by $20 \mathrm{E}$ we manipulated 20E levels and EcR receptors directly. Functional experiments were performed in four species of butterflies from different Nymphalid subfamilies, Idea leuconoe (Danainae), a control outgroup danainae with no EcR expression in its black spots, Vindula dejone (Nymphalinae), Doleschallia bisaltide (Nymphalinae), and B. anynana (Satyrinae), the latter three displaying EcR expression in their eyespot centers. Our prediction would be that Idea should not respond to $20 \mathrm{E}$ signaling at all, given the lack 
112 of the receptor in its spots, and that increases in $20 \mathrm{E}$ signaling at low temperature

113 might cause the eyespots of Vindula and Doleschalia to become smaller but those of $B$.

114 anynana to become larger, whereas decreases of $20 \mathrm{E}$ signaling at high temperature

115 might cause the eyespots of the first two species to become larger but smaler in $B$.

116 anynana. Injections of $20 \mathrm{E}$ into female wanderers reared at low temperature (and with

117 lower $20 \mathrm{E}$ titers) and of an EcR antagonist, CucB, into female wanderers reared at

118 high temperature (and with higher 20E titers), showed no response across the first

119 three species, whereas eyespot size significantly increased with $20 \mathrm{E}$ injections and

120 decreased with antagonist injections in B. anynana (Fig. 3). These data indicate that

121 only the eyespots of $B$. anynana are sensitive to $20 \mathrm{E}$ signaling, within the natural range

122 of titers displayed by these species. This sensitivity is a derived trait potentially

123 restricted to the satyrid sub-family within nymphalids (Fig. 4).

125 While multiple reports have focused on the role of hormones as mediators of trait 126 plasticity ${ }^{19-22}$, the physiological and developmental details of how a fully functional 127 plastic trait originates during the course of evolution were still obscure. Here we 128 identified the approximate evolutionary origins of individual components of a plastic 129 response of eyespot size in response to temperature and discovered this plastic 130 response to be a complex trait that evolved gradually via changes to different 131 molecular components. Our work showed that the origin of plasticity in hormone 132 titers, the origin of hormone receptor expression in the trait, and the origin of eyespot 133 sensitivity to these hormones all took place at different stages of nymphalid 134 diversification (Fig. 4).

136 An increase in eyespot size in response to temperature appears to be restricted to 137 satyrid butterflies, and is a derived response within nymphalids. Plasticity in eyespot 138 size in butterflies had been primarily documented in satyrid butterflies such as 
Melanitis leda and several Bicyclus species ${ }^{23-25}$ where size was always found to positively increase with rearing temperature. Most of the reared species of nymphalids and the papilionid species showed a slight decrease in eyespot/spot size with an increase in temperature, while some species showed no plasticity at all. This decrease in eyespot size with increasing temperature may simply reflect non-adaptive variation from a poorly canalized system. In addition, satyrid butterflies, but none of the other species, used the 20E asymmetry to regulate the size of their eyespots in a novel way. This was enabled by the prior recruitment of EcR to the eyespot central cells perhaps concurrently with eyespot origins (Fig. 4). These central signaling cells play an important role in determining eyespot size at the $\mathrm{Wr}$ stages of development ${ }^{26}$. Some species, such as Junonia coenia, retain expression of EcR in eyespots but only at other stages of wing development ${ }^{27}$. Finally, the active $20 \mathrm{E}-\mathrm{EcR}$ complexes increase eyespot size in B. anynana but not in other species with similar EcR expression in their eyespot centers. The ability of $20 \mathrm{E}$ to promote localized patterns of cell division might have evolved in the lineage leading to B. anynana alone ${ }^{7}$.

Eyespot size plasticity in connection with wet and dry seasonal forms is widely conserved across the sub-family Nymphalinae ${ }^{28}$ but our results suggest that different mechanisms may have evolved to regulate eyespot size plasticity in these lineages. Our controlled rearing experiments showed that all nymphalinae (Vanessa cardui, Junonia almana, J. coenia, J. atlites, J. iphita and Doleschallia bisaltide) produced only small changes in the size of the their $\mathrm{Cu} 1$ eyespots in response to rearing temperature, and these were in the opposite direction to those observed in B. anynana. Other environmental factors might cue and regulate these species' seasonal morphs (Fig. S2), perhaps cues that better predict the arrival of the seasons where these butterflies have evolved. Investigations at the proximate level will be required to correctly establish the environmental cues that induce seasonal forms in these other butterfly species. For 
166 now, we uncover phenotypic plasticity in eyespot size in B. anynana as a complex, step-

167 wise adaptation to seasonal environments cued by temperature that required very

168 specific mutations to originate. This work also serves as a warning that if all forms of

169 plasticity are as specific and hard to evolve as the one documented in B. anynana, these

170 exquisite adaptations to specific predictable fluctuating environments may in fact, lend

171 the species vulnerable to extinction under unpredictable climate change, as previously

172 noted ${ }^{29}$.

173

$174 \quad$ Figure legends

175

176

177

Figure 1. Eyespot/spot size plasticity is widespread across butterfly lineages but the response to rearing temperature has different norms of reaction across species. A. Size of hindwing ventral Cu1 eyespots (arrowheads). Thirteen species of butterflies were reared at two different rearing temperatures. Eyespot size corrected for wing size is plotted for two different temperatures (low temperature $17^{\circ} \mathrm{C}$ or $20^{\circ} \mathrm{C}$ is marked with blue symbols, while high temperature of $27^{\circ} \mathrm{C}$ or $30^{\circ} \mathrm{C}$ is marked with red symbols). Error bars represent 95\% CI of means.

B. Phylogenetic analysis suggests 3 independent origins for two different patterns of plasticity (eyespot size decreases with increasing temperatures: red lineages, and eyespot size increases with increasing temperature: green lineage). The ancestral reconstruction for the gain of negative plasticity is equivocal for two (shown) or three (not shown) gains. That is, it is equally parsimonious that negative plasticity was gained as shown or that it was gained three separate times: once leading to $I$. leucone, once leading to $V$. dejone, and once leading to the MRCA of $V$. cardui and $D$. bisaltide.

190

Figure 2. 20E titers increase with rearing temperature across most species but EcR expression in eyespots is only found in a subset of nymphalids. A. $20 \mathrm{E}$ titers increase with an increase in rearing temperature across most species. This trait is ancestral in nature, with a likely origin before the origin of eyespots. B. EcR is absent in simple spots, but present in the future eyespot centers of most of the species investigated ( $\mathrm{N} \geq 3$ for each immunostaining). 
199 Fig. 3. Sensitivity of eyespots to EcR mediated signaling originated in the

200 lineage leading to $\boldsymbol{B}$. anynana butterflies. Four species of butterflies were injected 201 with $20 \mathrm{E}$ hormones or EcR antagonists (CucB) during the $\mathrm{Wr}$ stage. While Idea 202 leuconoe, Vindula dejone and Doleschallia bisaltide are not sensitive to either of the hormone 203 signal manipulations, B. anynana shows sensitivity towards both 20E and CucB. Error 204 bars represent 95\% CI of means. Significant differences between treatments are represented by asterisks: ${ }^{* *}, \mathrm{p}<0.01,{ }^{* * *}, \mathrm{p}<0.001$.

208 Phylogenetic analysis suggests three or four independent origins for two different 209 patterns of plasticity (eyespot size decreases with increasing temperatures: red lineages 210 and - sign, and eyespot size increases with increasing temperature: green lineage and $211+$ sign). Green circles (character state 1) represents high 20E titers with increasing 212 temperature, while white circles (character state 0) represent no significant difference 213 in titers at two developmental temperatures. Green squares represent presence of EcR 214 in eyespots, while white squares represent its absence. EcR expression in eyespots is 215 inferred to have originated concurrently with the origin of eyespots, about 85 Mya, 216 and subsequently lost in a few nymphalid lineages. Green triangles represent 217 sensitivity towards $20 \mathrm{E}$ in respective species (character state 1), while white triangles 218 represent absence of sensitivity (character state 0). Gray circles, squares and triangles 219 represent missing data points. Alternative models using Maximum Likelihood reach similar conclusions (Supplementary Information). 
Figure 1:

A
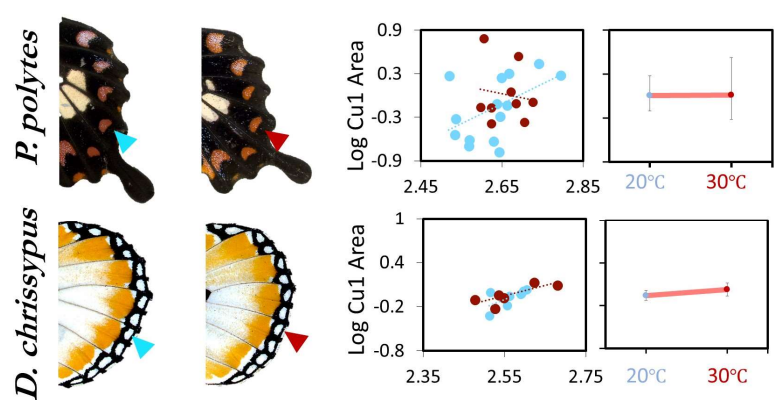

i
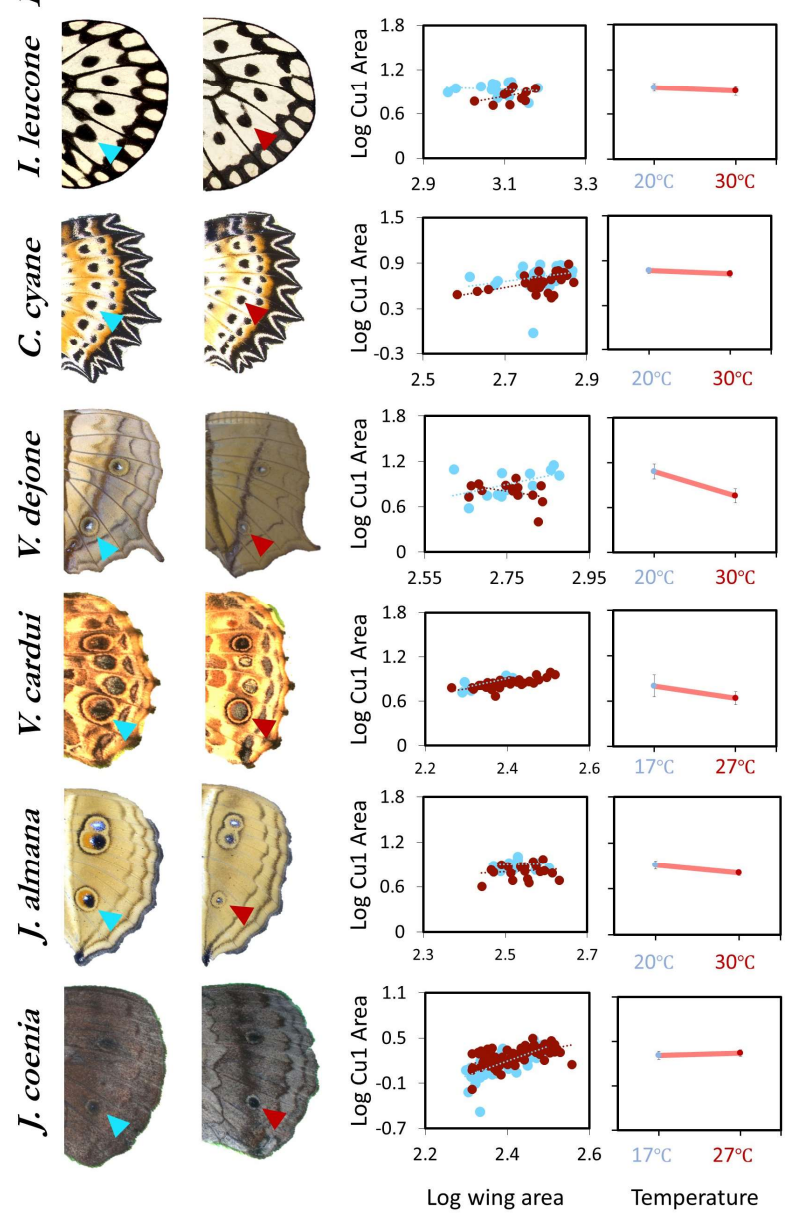
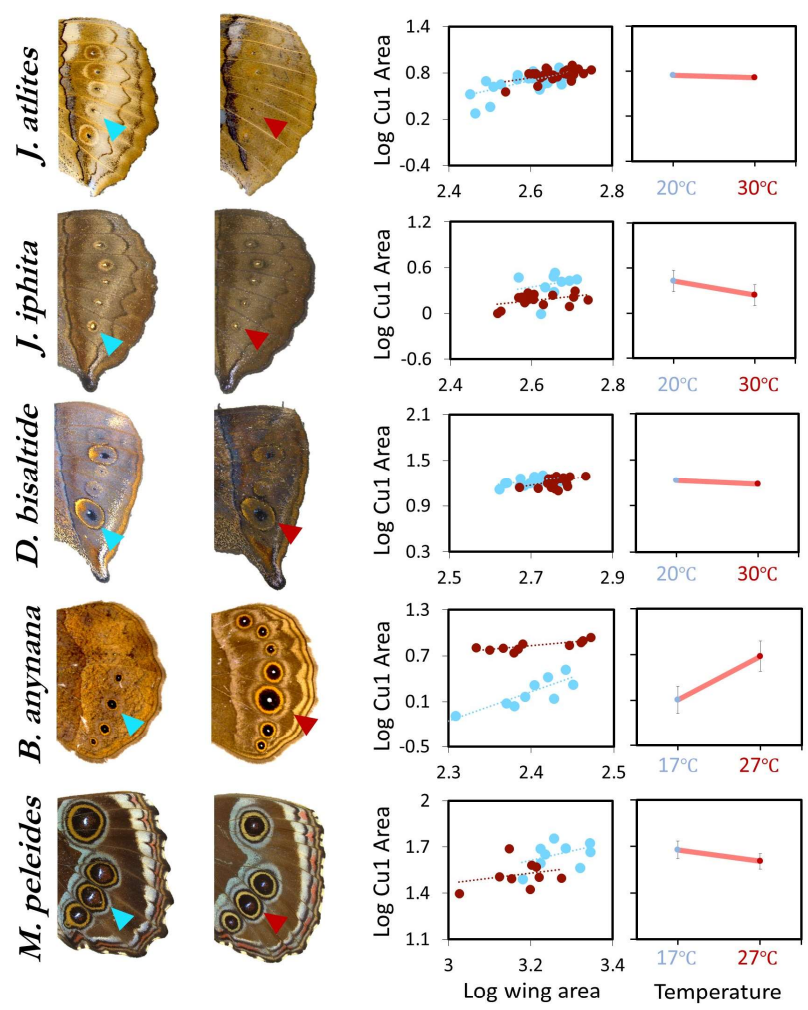

B
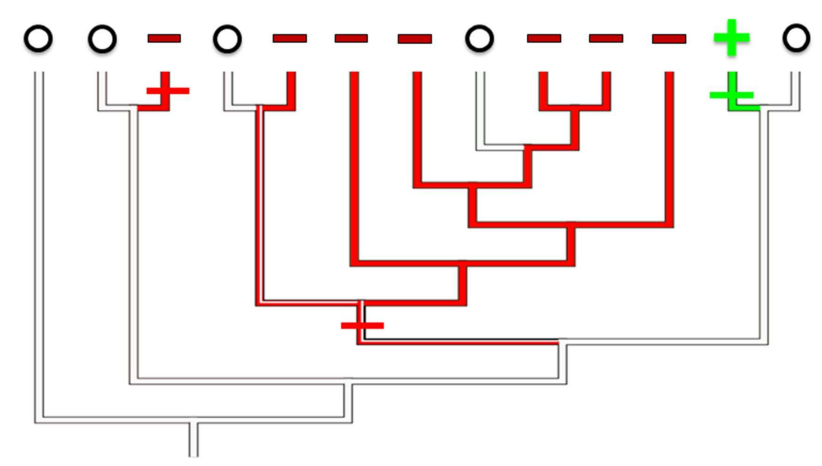
bioRxiv preprint doi: https://doi.org/10.1101/378836; this version posted July 27,2018 . The copyright holder for this preprint (which was not certified by peer review) is the author/funder, who has granted bioRxiv a license to display the preprint in perpetuity. It is made available under aCC-BY-ND 4.0 International license.

Figure 2

230

231

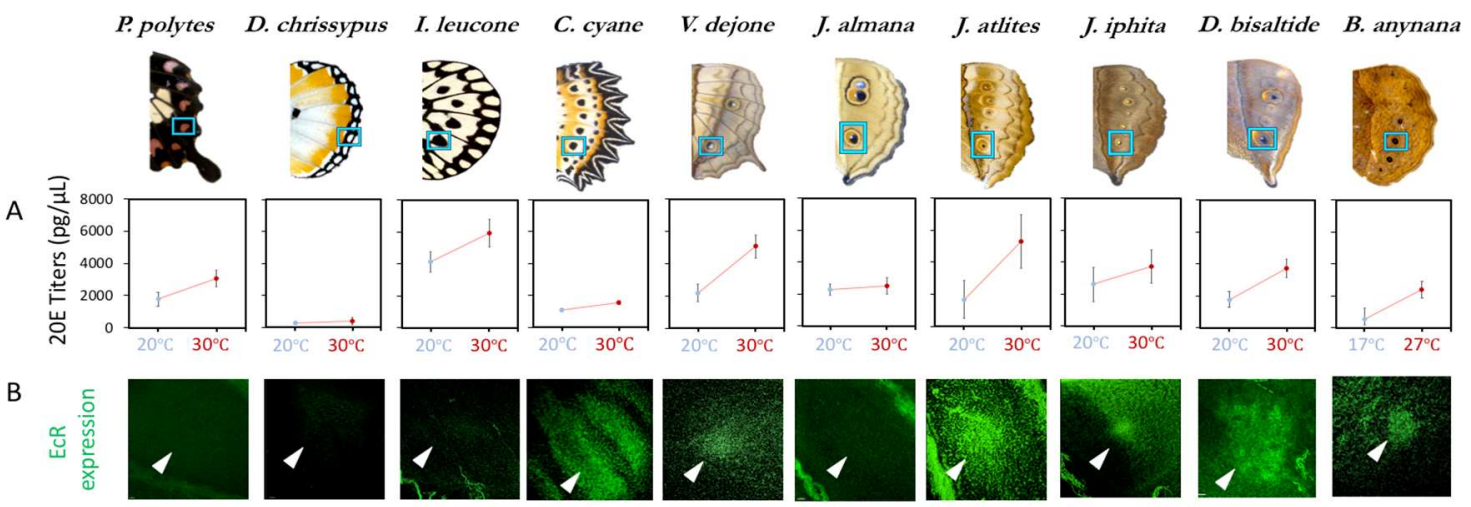



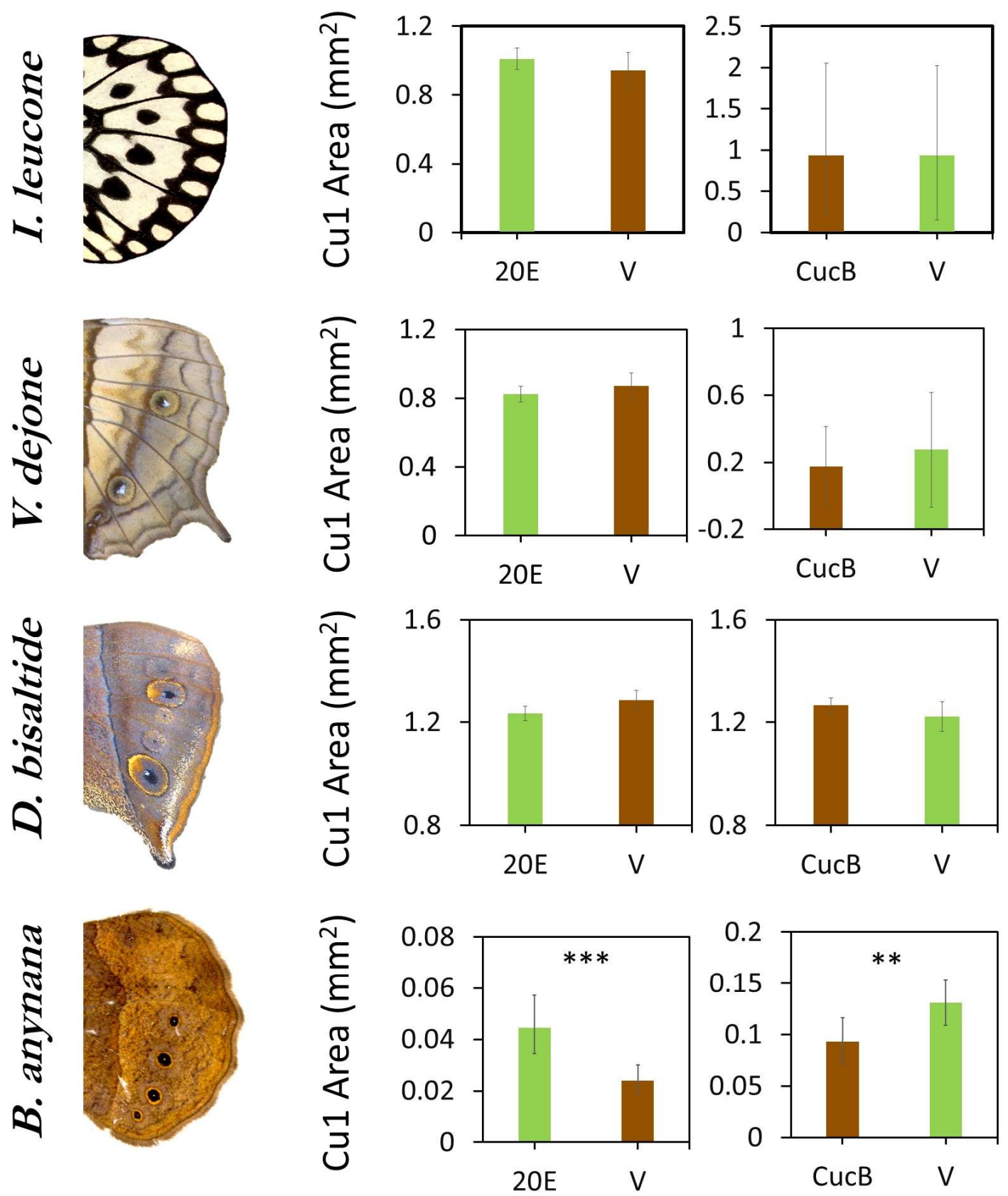

\section{Treatments}




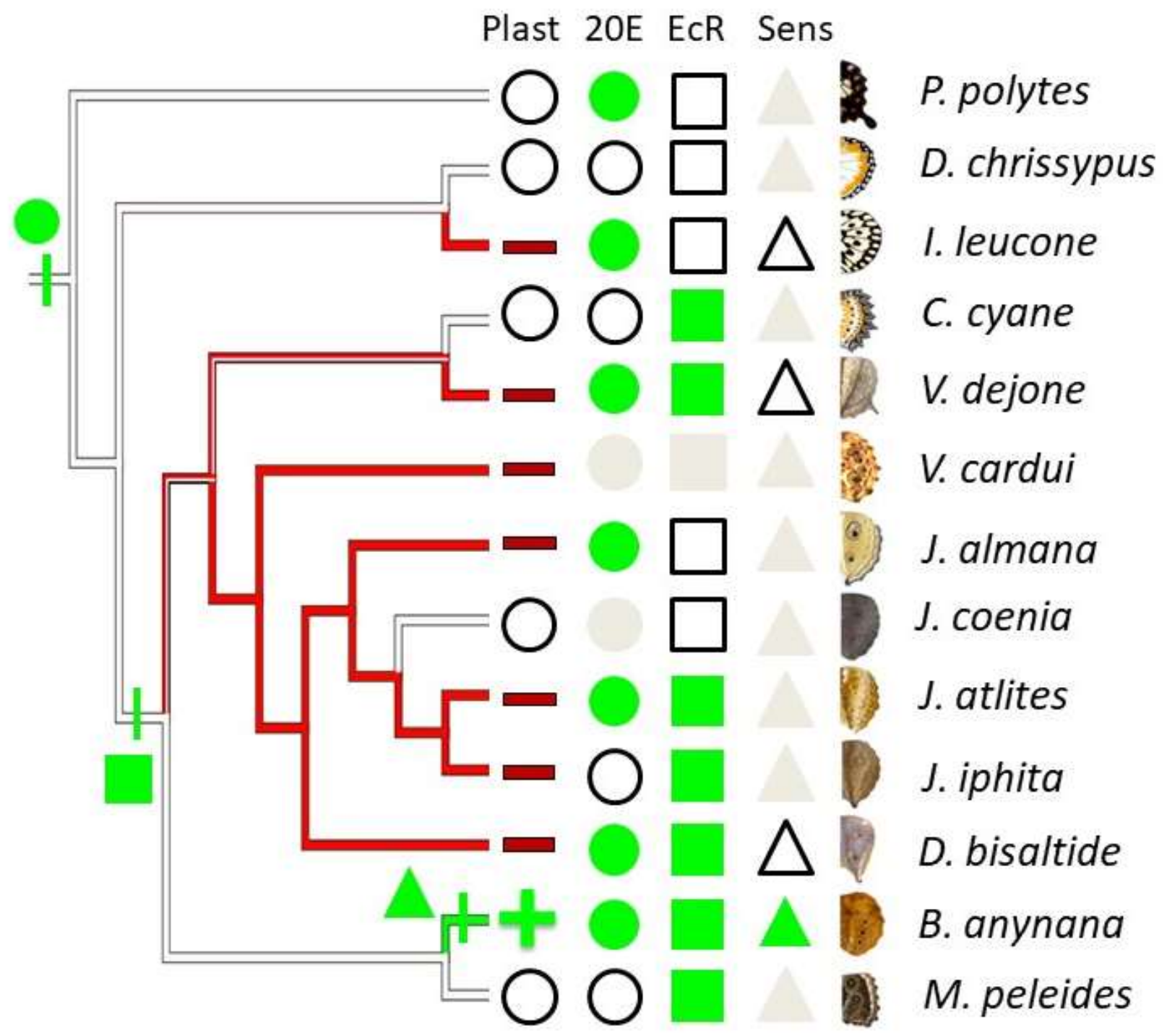




\section{References}

2471 de Jong, G. Evolution of phenotypic plasticity: patterns of plasticity and the emergence of ecotypes. New Phytol 166, 101-117, doi:10.1111/j.1469-8137.2005.01322.x (2005).

2492 Bradshaw, A. D. in Advances in Genetics Vol. 13 (eds E. W. Caspari \& J. M. Thoday) 115-155 $250 \quad$ (Academic Press, 1965).

2513 Pigliucci, M. Evolution of phenotypic plasticity: where are we going now? Trends in ecology \& evolution 20, 481-486, doi:https://doi.org/10.1016/j.tree.2005.06.001 (2005).

4 Laland, K. et al. Does evolutionary theory need a rethink? Nature 514, 161-164, doi:10.1038/514161a. (2014).

5 West-Eberhard, M. J. Developmental Plasticity and Evolution. (Oxford University Press, 2003).

2566 Monteiro, A. et al. Differential Expression of Ecdysone Receptor Leads to Variation in doi:10.1371/journal.pgen.1005529 (2015). dimorphism in Bicyclus anynana wing patterns. Molecular biology and evolution, tetrapods. Nature 513, 54, doi:10.1038/nature13708 (2014). Naturalist 139, 971-989 (1992). 
Hiyama, A., Taira, W. \& Otaki, J. M. Color-Pattern Evolution in Response to Environmental Stress in Butterflies. Frontiers in genetics 3, 15, doi:10.3389/fgene.2012.00015 (2012).

12 Kiontke, K. \& Fitch, D. H. A. Phenotypic Plasticity: Different Teeth for Different Feasts. Current Biology 20, R710-R712, doi:10.1016/j.cub.2010.07.009 (2010).

13 Brakefield, P. M. \& Reitsma, N. Phenotypic plasticity, seasonal climate and the population biology of Bicyclus butterflies (Satyridae) in Malawi. Ecological Entomology 16, 291-303, doi:10.1111/j.1365-2311.1991.tb00220.x (1991).

14 Brakefield, P. M. et al. Development, plasticity and evolution of butterfly eyespot patterns. Nature 384, 236-242, doi:10.1038/384236a0 (1996).

15 Prudic, K. L., Stoehr, A. M., Wasik, B. R. \& Monteiro, A. Eyespots deflect predator attack increasing fitness and promoting the evolution of phenotypic plasticity. Proc Biol Sci 282, 20141531, doi:10.1098/rspb.2014.1531 (2015).

16 Lyytinen, A., Brakefield, P. M., Lindström, L. \& Mappes, J. Does predation maintain eyespot plasticity in Bicyclus anynana? Proceedings of the Royal Society B: Biological Sciences 271, 279-283 (2004).

17 Oliver, J. C., Tong, X. L., Gall, L. F., Piel, W. H. \& Monteiro, A. A single origin for nymphalid butterfly eyespots followed by widespread loss of associated gene expression. PLoS Genet 8, e1002893, doi:10.1371/journal.pgen.1002893 (2012).

18 Oliver, J. C., Beaulieu, J. M., Gall, L. F., Piel, W. H. \& Monteiro, A. Nymphalid eyespot serial homologues originate as a few individualized modules. Proceedings of the Royal Society B: Biological Sciences 281, doi:10.1098/rspb.2013.3262 (2014).

1 Dai, H., Wu, X., \& Wu, S. The change of juvenile hormone titer and its relation with wing dimorphism of brown planthopper, Nilaparvata lugens. Acta Entom. Sin. 44, 27-32 (2001).

Emlen, D. J. \& Nijhout, H. F. Hormonal control of male horn length dimorphism in the dung beetle Onthophagus taurus (Coleoptera: Scarabaeidae). J Insect Physiol 45, 45-53 (1999). 
295

Gotoh, H. et al. Juvenile Hormone Regulates Extreme Mandible Growth in Male Stag Beetles. PLOS ONE 6, e21139, doi:10.1371/journal.pone.0021139 (2011).

22 Gotoh, H. et al. Developmental link between sex and nutrition; doublesex regulates sexspecific mandible growth via juvenile hormone signaling in stag beetles. PLoS Genet 10, e1004098, doi:10.1371/journal.pgen.1004098 (2014).

23 Brakefield, P. M. Tropical dry and wet season polyphenism in the butterfly Melanitis leda (Satyrinae): Phenotypic plasticity and climatic correlates. Biological Journal of the Linnean Society 31, 175-191, doi:10.1111/j.1095-8312.1987.tb01988.x (1987).

24 Roskam, J. C. \& Brakefield, P. M. Seasonal polyphenism in Bicyclus (Lepidoptera: Satyridae) butterflies: different climates need different cues. Biological Journal of the Linnean Society 66, 345-356, doi:10.1111/j.1095-8312.1999.tb01895.x (1999).

25 van Bergen, E. et al. Conserved patterns of integrated developmental plasticity in a group of polyphenic tropical butterflies. BMC Evolutionary Biology 17, 59, doi:10.1186/s12862-0170907-1 (2017).

26 Monteiro AF, Brakefield PM \& V, F. The Evolutionary Genetics and Developmental Basis of Wing Pattern Variation in the butterfly Bicyclus anynana. Evolution 48, 1147-1157, doi:doi: 10.1111/j.1558-5646.1994.tb05301.x.

27 Koch, P. B., Merk, R., Reinhardt, R. \& Weber, P. Localization of ecdysone receptor protein during colour pattern formation in wings of the butterfly Precis coenia (Lepidoptera: Nymphalidae) and co-expression with Distal-less protein. Dev Genes Evol 212, 571-584, doi:10.1007/s00427-002-0277-5 (2003).

28 Clarke, J. W. in Diversity and Evolution of Butterfly Wing Patterns: An Integrative Approach (eds Toshio Sekimura \& H. Frederik Nijhout) 239-253 (Springer Singapore, 2017).

Oostra, V., Saastamoinen, M., Zwaan, B. J. \& Wheat, C. W. Strong phenotypic plasticity limits potential for evolutionary responses to climate change. Nature communications $\mathbf{9}, \mathbf{1 0 0 5}$, doi:10.1038/s41467-018-03384-9 (2018). 

aCC-BY-ND 4.0 International license.

$32130 \quad$ Wahlberg, N. et al. Nymphalid butterflies diversify following near demise at the

322 Cretaceous/Tertiary boundary. Proceedings of the Royal Society B: Biological Sciences 276, 4295

$323 \quad(2009)$.

32431 Oliver, J. C. Microevolutionary processes generate phylogenomic discordance at ancient

325 divergences Evolution 67, 1823-1830, doi:10.1111/evo.12047 (2013). 


\section{Supplementary Information}

\section{Materials and methods}

Butterfly husbandry. B. anynana were raised from lab populations in Singapore, under temperature control chambers at $17^{\circ} \mathrm{C}$ and $27^{\circ} \mathrm{C}$, with a $12 \mathrm{~h}$ light: dark cycle and $80 \%$ RH. Vanessa cardui, and Morpho peleides were reared in climate chambers at Yale University, New Haven at $17^{\circ} \mathrm{C}$ and $27^{\circ} \mathrm{C}$. Junonia coenia was reared at $20^{\circ}$ and $30^{\circ} \mathrm{C}$ at $16 \mathrm{H}: 8 \mathrm{H}$ light: dark cycle at Duke University. All other species of butterflies were reared at Entopia (formerly, Penang Butterfly Farm, Penang, Malaysia) in temperature controlled chambers (PT2499 Incubator, Exoreptiles, Malaysia) at $20^{\circ} \mathrm{C}$ and $30^{\circ} \mathrm{C} .70 \% \mathrm{RH}$ was maintained and monitored using (PT2470 Hygrometer, Exoreptiles, Malaysia) and EL-USB-2 data loggers (Lascar Electronics, PA 16505, USA).

Four hours after emergence, butterflies were captured and frozen in glassine envelopes at $-20^{\circ} \mathrm{C}$. All larvae in this experiment were sexed during larval or pupal stages and only females were used for analysis. Wings were carefully dissected and imaged using a Leica upright microscope. Wing images were processed in ImageJ, where area and eyespot size were measured using selection tools.

Haemolymph collection. Previous studies in B. anynana have pointed to the wandering $(\mathrm{Wr})$ stage as the critical temperature sensitive stage for determination of ventral hindwing eyespot size ${ }^{6}$. Time lapse photographs of larval development were captured using a RICOH camera to determine the beginning of the Wr stage across all species. Initiation of Wr stage is marked by the larvae stopping to feed, purging their gut, and starting to wander away from the food and looking for a place to pupate. Using Hamilton syringes, $20 \mathrm{uL}$ of haemolymph, were extracted from each larvae at $\sim 70 \%$ development in $\mathrm{Wr}$ stage $\left(15 \mathrm{~h}\right.$ after $\mathrm{Wr}$ started for animals reared at $30^{\circ} \mathrm{C}$, and 
$25 \mathrm{~h}$ for animals reared at $20^{\circ} \mathrm{C}$ ). Extracted haemolymph was then dissolved in freshly prepared 90ul methanol $+90 \mathrm{ul}$ isooctane and stored at $-20^{\circ} \mathrm{C}$ until hormone extraction ${ }^{7}$.

Wing tissue collection. Larval wing discs were dissected from Wr stage larvae and stored in fix buffer until further processing at $4^{\circ} \mathrm{C}$. These were later stained for EcR expression using a primary antibody 15F1 (DSHB) raised against a Manduca sexta EcR peptide shared across all isoforms of EcR, and secondary antibody AlexaFlour 488 green. Spalt, a nuclear marker for spots and eyespots, was used as a location marker for putative eyespots/spots in the larval wings. Serial optical sections of the Cu1 eyespot wing sector were imaged using LSM510 Meta, to distinguish between dorsal and ventral surfaces. Specific slices were obtained from raw images using Imaris v8.64 (ImarisXT, Bitplane AG, software available at http://bitplane.com. Junonia coenia EcR data were taken from Koch and Nijhout, $2003^{27}$.

$20 \mathrm{E}$ and antagonist injections. Four species of butterflies, Idea leuconoe, Vindula dejone, Doleschallia bisaltide, and B. anynana, were injected with 20E or CucB during the Wr stage. Injections were made at $\sim 50 \%$ development of $\mathrm{Wr}$ stage $\left(12-14 \mathrm{~h}\right.$ at $30^{\circ} \mathrm{C}$, $18-22 \mathrm{~h}$ at $20^{\circ} \mathrm{C}$; For B.anynana, rearing were done at $27^{\circ} \mathrm{C}$ and $17^{\circ} \mathrm{C}$ respectively). Average body weights of wandering larvae and total haemolymph present were calculated for each species, and used to calculate naturally circulating $20 \mathrm{E}$ levels in vivo. A gradient of different concentrations of $20 \mathrm{E}$ and $\mathrm{CucB}$ were used for pilot experiments. Maximum concentrations of $20 \mathrm{E}$, which did not surpass the natural levels, and of $\mathrm{CucB}$, which did not cause mortality or pupation defects, were used for injections and are summarized in the table below. 20E and $\mathrm{CucB}$ were dissolved in $10 \% \mathrm{EtOH}$ to make working solution for injections. Equal volume injections of Vehicle $(10 \% \mathrm{EtOH}$ in Saline) injections were done as controls. After injections, 
381 animals were reared at their regular rearing temperature $\left(17^{\circ} \mathrm{C}\right.$ for B.anynana, $20^{\circ} \mathrm{C}$ for

382 other $20 \mathrm{E}$ injected animals and $27^{\circ} \mathrm{C}$ for B.anynana, $30^{\circ} \mathrm{C}$ for CucB injected animals)

383 until emergence as adults. After emergence, the wings were dissected, imaged, and

384 scored for further analysis.

385

386 Statistical analysis. All wing and eyespot data were log10 transformed to ensure

387 linearity of wing size with eyespot size for purposes of allometric scaling and 388 regression analysis, and to be able to compare slopes across species with different eyespot sizes and wing sizes. Univariate ANCOVAs were performed using hindwing

390 Cu1 eyespot area as the main variable, hindwing area as a covariate, and rearing 391 temperature as a fixed factor in SPSS v21. Graphs were plotted in Microsoft Office 3922016 for Mac. Slopes for plasticity of eyespot size and 20E titers were measured using 393 the expression:

$$
\text { Slope }=\frac{\text { (Value at hightemperature }- \text { Value at low temperature })}{\text { Difference } \square \text { rearing temperature }\left(10^{\circ} \mathrm{C}\right)}
$$

396

397 Using reverse transformed data for eyespot size, and untreated values for hormone 398 titers. 
Table S1: Species reared for comparative morphometrics, gene expression and hormonal measurements

\begin{tabular}{|c|c|c|c|c|c|c|}
\hline Species & $\begin{array}{c}\text { Family/Nymphalid } \\
\text { Subfamily }\end{array}$ & \begin{tabular}{|c|} 
Spots/ \\
Eyespots
\end{tabular} & $\begin{array}{c}\text { Rearing } \\
\text { temp. } \\
\left({ }^{\circ} \mathrm{C}\right)\end{array}$ & $\begin{array}{c}\text { Source of } \\
\text { animals used in } \\
\text { experiments }\end{array}$ & $\begin{array}{c}\text { Climatic conditions } \\
\text { (Köppen classification) }\end{array}$ & \begin{tabular}{|c|} 
Reported \\
Seasonality in \\
Spot/Eyespot \\
Size
\end{tabular} \\
\hline $\begin{array}{l}\text { Junonia } \\
\text { atlites }\end{array}$ & Nymphalidae/Nymphalinae & Eyespots & $20 / 30$ & Malaysia & $\begin{array}{c}\text { Tropical; } \\
\text { Equatorial humid (Af) }\end{array}$ & No \\
\hline $\begin{array}{c}\text { Junonia } \\
\text { coenia }\end{array}$ & Nymphalidae/Nymphalinae & Eyespots & $20 / 30$ & USA & Subtropical & No \\
\hline $\begin{array}{c}\text { Junonia } \\
\text { iphita }\end{array}$ & Nymphalidae/Nymphalinae & Eyespots & $20 / 30$ & Malaysia & $\begin{array}{c}\text { Tropical; } \\
\text { Equatorial humid (Af) }\end{array}$ & No \\
\hline $\begin{array}{l}\text { Junonia } \\
\text { almana }\end{array}$ & Nymphalidae/Nymphalinae & Eyespots & $20 / 30$ & Malaysia & $\begin{array}{c}\text { Tropical; } \\
\text { Equatorial humid (Af) }\end{array}$ & Yes \\
\hline $\begin{array}{c}\text { Doleschallia } \\
\text { bisaltide }\end{array}$ & Nymphalidae/Nymphalinae & Eyespots & $20 / 30$ & Malaysia & $\begin{array}{c}\text { Tropical; } \\
\text { Equatorial humid (Af) }\end{array}$ & No \\
\hline $\begin{array}{l}\text { Vanessa } \\
\text { cardui }\end{array}$ & Nymphalidae/Nymphalinae & Eyespots & $17 / 27$ & USA & Subtropical & No \\
\hline $\begin{array}{l}\text { Vindula } \\
\text { dejone }\end{array}$ & Nymphalidae/Heliconinae & Eyespots & $20 / 30$ & Malaysia & $\begin{array}{c}\text { Tropical; } \\
\text { Equatorial humid (Af) }\end{array}$ & No \\
\hline $\begin{array}{c}\text { Cethosia } \\
\text { cynae }\end{array}$ & Nymphalidae/Heliconinae & Eyespots & $20 / 30$ & $\begin{array}{l}\text { Singapore, } \\
\text { Malaysia }\end{array}$ & $\begin{array}{c}\text { Tropical; } \\
\text { Equatorial humid (Af) }\end{array}$ & No \\
\hline $\begin{array}{l}\text { Bicyclus } \\
\text { anynana }\end{array}$ & Nymphalidae/Satyrinae & Eyespots & $17 / 27$ & Africa & $\begin{array}{c}\text { Tropical; } \\
\text { Equatorial, winter dry } \\
(\mathrm{Aw})\end{array}$ & Yes \\
\hline $\begin{array}{l}\text { Morpho } \\
\text { peleides }\end{array}$ & Nymphalidae/Morphinae & Eyespots & $17 / 27$ & Costa Rica & Subtropical & No \\
\hline $\begin{array}{l}\text { Danaus } \\
\text { chryssipus }\end{array}$ & Nymphalidae/Danainae & Spots & $20 / 30$ & Malaysia & $\begin{array}{c}\text { Tropical; Equatorial } \\
\text { humid (Af) }\end{array}$ & No \\
\hline Idea leuconoe & Nymphalidae/Danainae & Spots & $20 / 30$ & Taiwan & $\begin{array}{c}\text { Subtropical; Warm, } \\
\text { humid, hot summers } 30\end{array}$ & No \\
\hline $\begin{array}{l}\text { Papilio } \\
\text { polytes }\end{array}$ & Papilionidae - Outgroup & Spots & $20 / 30$ & Malaysia & $\begin{array}{c}\text { Tropical; Equatorial } \\
\text { humid (Af) }\end{array}$ & $\mathrm{No}$ \\
\hline
\end{tabular}


Table S2 : F statistics, p-values from analysis of covariance for differences in $\mathrm{Cu} 1$ eyespot size between rearing temperatures (fixed factor) and assigned

410 character state for phylogenetic analysis. Wing size was used as a covariate. Rows

411 highlighted in red indicate species where eyespot size decreases significantly with

412 rearing temperature (negative slope). Species highlighted in green shows the opposite

413 pattern (a significant positive slope). Character states of $-1=$ negative slope; $0=$ no

414 plasticity; $1=$ positive slope.

\begin{tabular}{|l|l|l|l|l|l|l|c|}
\hline Species & $\begin{array}{l}\text { Family/ } \\
\text { Subfamily }\end{array}$ & Factor & F stats & P value & $\begin{array}{l}\text { DF (Factor, } \\
\text { Error) }\end{array}$ & $\begin{array}{l}\text { Slope of } \\
\text { reaction norm }\end{array}$ & $\begin{array}{l}\text { Character } \\
\text { state }\end{array}$ \\
\hline Papilio polytes & Papilionidae & temp. & 0.360 & 0.360 & 1,59 & 0.000 & 0 \\
\hline Danaus chrysippus & Danainae & temp. & 0.318 & 0.585 & 1,59 & 0.008 & 0 \\
\hline Idea leucone & Danainae & temp. & 10.073 & 0.031 & 1,59 & -0.004 & -1 \\
\hline Cethosia cyane & Heliconinae & temp. & 0 & 0.096 & 1,59 & -0.004 & 0 \\
\hline Vindula dejone & Heliconinae & temp. & 8.247 & 0.009 & 1,59 & -0.032 & -1 \\
\hline Vanessa cardui & Nymphalinae & temp. & 15.056 & 0.001 & 1,59 & -0.016 & -1 \\
\hline Junonia almana & Nymphalinae & temp. & 15.832 & $<0.001$ & 1,59 & -0.010 & -1 \\
\hline Junonia coenia & Nymphalinae & temp. & 0.888 & 0.352 & 1,59 & 0.003 & 0 \\
\hline Junonia atlites & Nymphalinae & temp. & 4.683 & 0.011 & 1,59 & -0.002 & -1 \\
\hline Junonia iphita & Nymphalinae & temp. & 11.670 & 0.042 & 1,59 & -0.018 & -1 \\
\hline Doleschallia bisaltide & Nymphalinae & temp. & 13.170 & 0.001 & 1,59 & -0.005 & -1 \\
\hline Bicyclus anynana & Satyrinae & temp. & 42.769 & $<0.001$ & 1,59 & 0.057 & 1 \\
\hline Morpho peleides & Morphinae & temp. & 0.765 & 0.393 & 1,19 & -0.007 & 0 \\
\hline
\end{tabular}


Table S3 : F statistics, p-values from analysis of covariance for differences in $20 \mathrm{E}$ hormone titers between rearing temperatures (fixed factor) and assigned character states for phylogenetic analysis. Wing size was used as a covariate. All data were $\log 10$ transformed to ensure linear allometries and comparable variances across temperature treatments. Rows highlighted in green indicate species where $20 \mathrm{E}$ titers increase significantly with rearing temperature (positive slope). Character state of $0=$ no plasticity; $1=$ positive slope.

\begin{tabular}{|c|c|c|c|c|c|c|}
\hline Species & Factor & F stats & $\begin{array}{c}\text { Slope of } \\
\text { reaction norm }\end{array}$ & P value & $\begin{array}{c}\text { DF (Factor, } \\
\text { Error) }\end{array}$ & Character state \\
\hline Papilio polytes & Temperature & 0.004 & 126.087 & $<0.0001$ & 1,10 & 1 \\
\hline Danaus chrysippus & Temperature & 1.234 & 12.424 & 0.293 & 1,10 & 0 \\
\hline Idea leucone & Temperature & 0.000 & 176.991 & $<0.0001$ & 1,17 & 1 \\
\hline Cethosia cyane & Temperature & 0.000 & 45.831 & 0.248 & 1,15 & 0 \\
\hline Vindula dejone & Temperature & 10.199 & 289.120 & 0.005 & 1,17 & 1 \\
\hline Junonia almana & Temperature & 5.830 & 24.134 & 0.034 & 1,25 & 1 \\
\hline Junonia atlites & Temperature & 46.370 & 547.639 & $<0.0001$ & 1,11 & 1 \\
\hline Junonia iphita & Temperature & 1.537 & 112.302 & 0.255 & 1,9 & 0 \\
\hline Doleschallia bisaltide & Temperature & 31.481 & 192.753 & $<0.0001$ & 1,10 & 1 \\
\hline Bicyclus anynana & Temperature & 34.304 & 185.891 & $<0.0001$ & 1,59 & 1 \\
\hline
\end{tabular}

Table 4 Mean body weight of wandering larvae, haemolymph volume and natural 20E titers at two different rearing temperatures; $20 \mathrm{E}$ and $\mathrm{CucB}$

428 injection volume. ( $N=5$ for measurement of means)

\begin{tabular}{|c|c|c|c|c|c|c|c|c|c|c|}
\hline \multirow{2}{*}{ Species } & \multirow{2}{*}{$\begin{array}{l}\text { Mean } \\
\text { body } \\
\text { weight }\end{array}$} & \multirow{2}{*}{$\begin{array}{c}\text { Mean total } \\
\text { haemolymph } \\
\text { volume }\end{array}$} & \multicolumn{2}{|c|}{$\begin{array}{l}\text { Total 20E } \\
\text { (in pg) }\end{array}$} & \multicolumn{3}{|c|}{$20 \mathrm{E}$ injection } & \multicolumn{3}{|c|}{ CucB injection } \\
\hline & & & $20^{\circ} \mathrm{C}$ & $30^{\circ} \mathrm{C}$ & Volume & $\begin{array}{l}\text { Concentration } \\
(\mathrm{pg} / \mu \mathrm{L})\end{array}$ & $\begin{array}{l}\text { Total } \\
\text { (in pg) }\end{array}$ & Volume & \begin{tabular}{|c|}
$\begin{array}{c}\text { Concentration } \\
(\mathrm{pg} / \mu \mathrm{L})\end{array}$ \\
\end{tabular} & \begin{tabular}{|l} 
Total \\
(in pg)
\end{tabular} \\
\hline $\begin{array}{c}\text { Idea } \\
\text { leuconoe }\end{array}$ & $0.63 \mathrm{~g}$ & $142 \mathrm{uL}$ & 497500 & 709890 & $4 \mu \mathrm{l}$ & 20000 & 80,000 & $3 \mu \mathrm{l}$ & 20000 & 60000 \\
\hline $\begin{array}{l}\text { Vindula } \\
\text { dejone }\end{array}$ & $0.45 \mathrm{~g}$ & $88 \mathrm{uL}$ & 191079 & 445505 & $3 \mu l$ & 10000 & 30000 & $3 \mu \mathrm{l}$ & 10000 & 30000 \\
\hline D. bisaltide & $0.49 \mathrm{~g}$ & $95 \mathrm{uL}$ & 170026 & 353142 & $3 \mu l$ & 7000 & 21000 & $3 \mu l$ & 10000 & 30000 \\
\hline B. anynana & $0.19 \mathrm{~g}$ & $61 \mathrm{uL}$ & 85104 & 144165 & $3 \mu \mathrm{l}$ & 2000 & 6000 & $2 \mu l$ & 5600 & 10,200 \\
\hline
\end{tabular}


Phylogenetic analysis. Patterns of plasticity in eyespot size were categorised in distinct groups based on positive, negative, or slopes undistinguishable from zero when eyespot size was plotted against temperature. Using a pruned version of a larger phylogenetic tree for all nymphalid genera ${ }^{30,31}$, ancestral trait reconstructions were performed and evolution of the reaction norm slopes were mapped using maximum parsimony in Mesquite. Similar analyses were performed using data obtained for hormone titer plasticity where species were categorised into two categories - those with a positive slope or a zero slope, and data for presence or absence of EcR expression, and 20E-EcR signaling affecting eyespot size.

We also evaluated several hypotheses concerning the evolution of relevant traits with likelihood ratio tests (LRT) and Akaike Information Criteria (AIC). For all analyses, specific ancestral nodes of interest were "fixed" for a particular state and the resultant maximum likelihood score was used for LRT and AIC comparisons ${ }^{18}$. We performed four tests in all, investigating (1) whether the most recent common ancestor (MRCA) to all butterflies (node 14 in Fig. S1) had plasticity in spot and eyespot size or not; (2) whether the MRCA to all butterfly species with eyespots (node 17) had plasticity in eyespot size or not; (3) whether the MRCA to all butterflies (node 14) had positive hormone titre plasticity or not; and (4) whether the MRCA to all butterfly species with eyespots (node 17) expressed EcR in the locations of future spots / eyespots or not. For tests of eyespot size plasticity, we used a three-state coding scheme: positive size plasticity, negative size plasticity, and no plasticity. Character states were scored based on the sign of the slope of the reaction norm; species with reaction norms that were not significantly different from zero were scored as having no temperature-dependent plasticity in eyespot size (Table S2). Tests on positive hormone titre plasticty and EcR expression used characters coded as binary states. For AIC comparisons, we used the correction for small sample sizes (AICc) and evaluated models based on the AICc 
459

460

461

462

463

464

465

466

467

468

469

470

471

472

473

474

weight, $w_{i}=\mathrm{e}^{((\min (\mathrm{AICc}-\mathrm{AICc}) / 2)}$. Models were considered significantly different if they differed by 2 or more log-likelihood units or the AICc weight was less than 0.2.

For all comparisons, there was little significant support for one hypothesis over another (Table S5). In tests on the origin of eyespot size plasticity, both the MRCA to all butterflies and the MRCA to all butterflies with eyespots had slightly better likelihood and AICc scores for being non-plastic than being plastic. Positive hormone titre plasticity in the MRCA to all butterflies had more support than a non-plastic MRCA, although the difference in likelihoods and AICc was not significant. Finally, the absence of EcR expression in the MRCA of all eyespot-bearing butterflies had higher likelihood and AICc scores than a model in which the MRCA did express EcR in future spot / eyespot centers. The absence of significant support for one model over another is largely due to the low number of species examined.

Table S5. Results of likelihood ratio tests and AIC comparisons. See Fig. S1 for node identities.

\begin{tabular}{lllcccc}
\hline Character & Node & State & $-\ln L$ & $\Delta \operatorname{lnL}$ & AICc & $w_{i}$ \\
\hline Size plasticity & 14 & Negative slope & 14.291 & 0 & 30.917 & 1.0 \\
\hline & & Flat slope & 14.559 & 0.267 & 31.450 & 0.766 \\
\hline & Positive slope & Negative slope & 15.084 & 0.792 & 32.501 & 0.453 \\
\hline & & Flat slope & 14.195 & 0 & 30.724 & 1.0 \\
\hline 20 Hormone titre & 14 & Positive slope & 14.948 & 0.453 & 31.630 & 0.636 \\
\hline & & No plasticity & 15.120 & 0.925 & 32.574 & 0.397 \\
\hline EcR expression & 18 & EcR absent & 7.285 & 0 & 19.661 & 1.0 \\
\hline & & EcR present & 7.716 & 0.431 & 20.523 & 0.650 \\
\hline
\end{tabular}




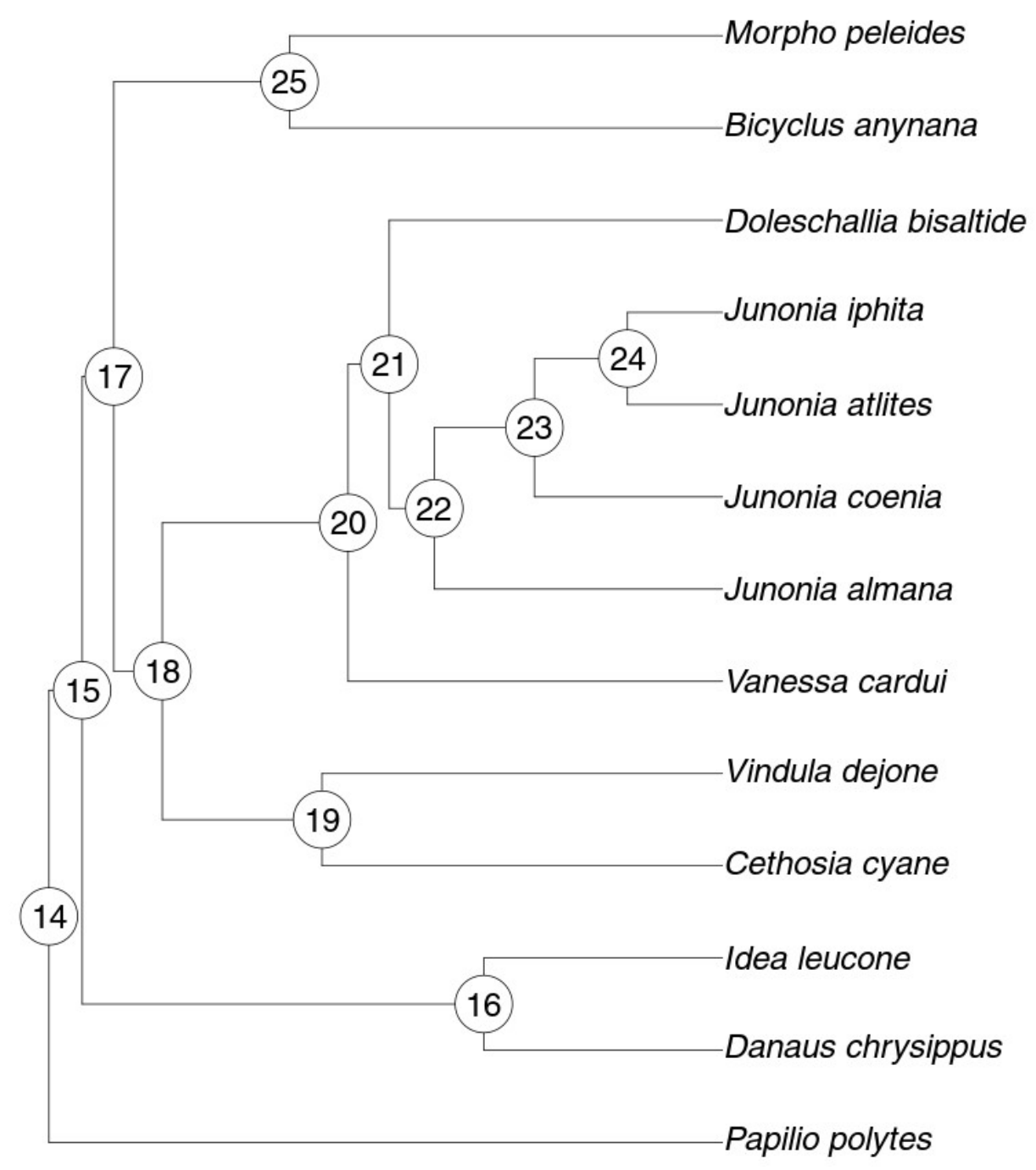

475 Fig. S1 Tree used for ancestral state hypotheses tests. See text for explanation of 476 node numbers.

477

478

479

480 


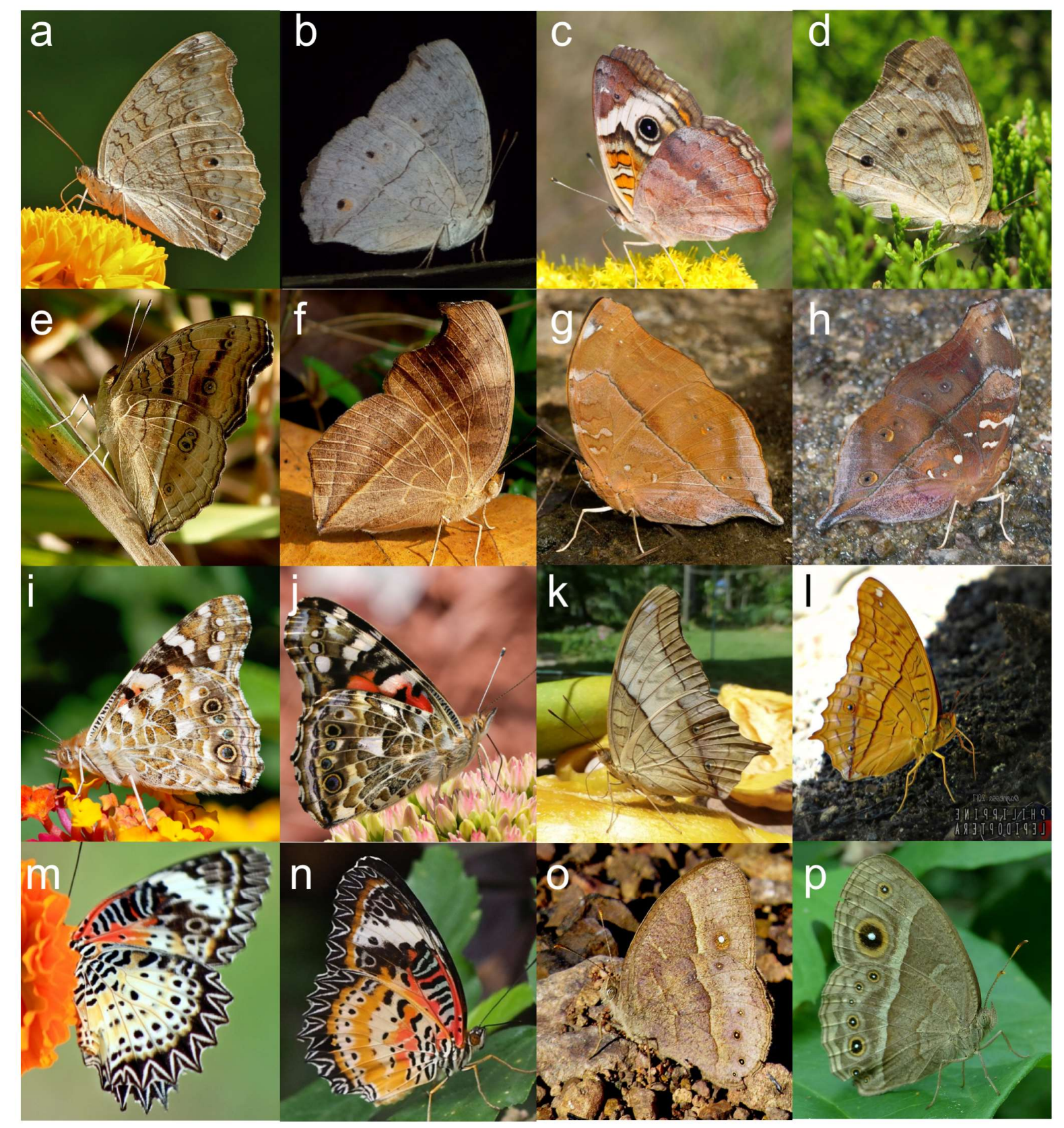

482 Fig. S2 Phenotypic plasticity in wing patterns is observed across a wide variety

483 of species in wild. a,b- Wet and Dry season forms of Junonia atlites; c,d- Seasonal 484 forms of Junonia coenia; e,f- Seasonal forms in Junonia alamana; $\mathrm{g}$,h- Differences in wing 485 patterns across seasons in Doleschalia bisaltide; i,j- Vanessa cardui produces exquisite 486 seasonal phenotypes; k,l- Seasonal variations in Vindula dejone; m,n- Seasonal forms in 487 Cethosia cynae; o,p - Dry and Wet seasonal forms of Bicyclus anynana. Pictures are 488 collected from crowdsourced repositories and copyrights belong to respective owners. 489 Seasonal forms have been associated with reported time of collection. 
490

491

492

493

494

495

496

497

498

499

500

501

502

503

504

505

506

507

508 Formal analysis : SB, LSHJ, JCO, AM

509 Supervision, Funding Acquisition : AM

510 Writing - Original Draft Preparation : SB

511 Writing - Review and Editing: AM

512

\section{Competing interests}

514 The author(s) declare no competing interests. 
bioRxiv preprint doi: https://doi.org/10.1101/378836; this version posted July 27,2018 . The copyright holder for this preprint (which was not certified by peer review) is the author/funder, who has granted bioRxiv a license to display the preprint in perpetuity. It is made available under aCC-BY-ND 4.0 International license. 